\title{
BIOPORI DAN BIOGRANUL KOMPOS SEBAGAI UPAYA PENINGKATAN PEDULI LINGKUNGAN DI SMAN 4 KABUPATEN SOPPENG
}

\author{
Santosa S. 1), E. Soekendarsi ${ }^{2) ， M . S . ~ H a s s a n ~}{ }^{3)}$, Fahruddin ${ }^{4)}$, M. Litaay ${ }^{\text {5) }}$ D. Priosambodo ${ }^{6}$ \\ ${ }_{1,2,3,4,5,6)}$ Fakultas Matematika dan Ilmu Pengetahuan Alam Universitas Hasanuddin \\ E-Mail : slametsantosa@unhas.ac.id
}

\begin{abstract}
Abstrak
Teknologi resapan biopori mempunyai fungsi ganda yaitu meresapkan air dan tempat pengomposan sampah organik. Peresapan air membantu mengurangi air genangan dan sekaligus meningkatkan ketersediaan air tanah. Pengomposan sampah organik mengurangi sumber pencemaran lingkungan hidup dan komposnya memperbaiki kualitas tanah. Teknologi resapan biopori dimulai dari pengeboran tanah dan memasukkan pipa paralon ukuran 3 inchi. Lubang resapan air ini dapat dijadikan tempat pengomposan sampah organik. Sampah organik dalam lubang resapan biopori memicu kehadiran organisme tanah seperti cacing, semut dan rayap. Aktifitas organisme tanah menyebabkan terbentuknya lubang (biopori) yang menjadi jalan air dan udara didalam tanah. Kegiatan ini memotivasi warga sekolah SMAN 4 kabupaten Soppeng untuk peduli pada lingkungan. Hasil kegiatan menunjukkan bahwa warga sekolah mempunyai pengetahuan dan memahami fungsi ganda lubang resapan biopori yaitu peningkatan ketersediaan air tanah dan produksi biogranul kompos. Dengan pengetahuan biopori dan biogranul diharapkan warga sekolah termotivasi menuju sekolah Adiwiyata.
\end{abstract}

Kata kunci : biopori, biogranul, peduli lingkungan.

\section{PENDAHULUAN}

Biopori merupakan lubang yang sangat kecil yang ada didalam tanah. Keberadaan biopori menyebabkan air hujan masuk ke dalam tanah sehingga mempengaruhi kualitas kesuburan tanah. Saat ini para pencinta lingkungan berupaya untuk meningkatkan biopori dengan cara membuat lubang resapan biopori. Lubang resapan biopori dapat menjadi tempat pengomposan sampah organik. Komposnya dapat dibentuk menjadi biogranul untuk mempermudah penggunaannya. Brata (2009), biopori merupakan ruangan atau pori dalam tanah yang dibentuk oleh makhluk hidup, seperti fauna tanah dan akar tanaman. Bentuk biopori menyerupai liang (terowongan kecil) dan bercabang-cabang yang sangat efektif untuk menyalurkan air dan udara ke dan di dalam tanah. Liang pada biopori terbentuk oleh adanya pertumbuhan dan perkembangan akar tanaman di dalam tanah serta meningkatnya aktifitas fauna tanah, seperti cacing tanah, rayap, dan semut yang menggali liang di dalam tanah. Isroi (2010), kompos/pupuk organik bisa dibuat dalam bermacam-macam bentuk, yaitu curah, table, pelet, briket, atau granul. Pemilihan bentuk ini tergantung pada penggunaan, biaya, dan aspek-aspek pemasaran lainnya. Salah satu bentuk yang banyak dipakai adalah granul. Pembuatan pupuk granul tidak sulit dan dapat dilakukan dimana saja tanpa peralatan yang mahal .Granul dari kompos hijauan ini dapat diperkaya kandungan nutrisi dengan penambahan limbah air beras yang dicampurkan pada saat pembentukan granul. Wulandari et.al. (2011) limbah cucian air beras mengandung banyak protein dan beberapa vitamin.

Biopori dan biogranul kompos merupakan teknologi ramah lingkungan dan mudah dilakukannya. Pelatihan pembuatan biopori dan biogranul kompos meningkatkan kesadaran warga sekolah untuk peduli lingkungan. Arifin (2012), teknologi resapan biopori mempunyai fungsi ganda yaitu meresapkan air dan tempat memproduksi kompos. Peresapan air akan membantu mengurangi air genangan dan sekaligus meningkatkan ketersediaan air tanah. Pengomposan sampah organik dalam lubang resapan biopori akan mendorong kehadiran fauna tanah seperti cacing, rayap dan serangga tanah lainnya. Aktifitas fauna tanah tersebut menyebabkan terbentuknya pori (biopori) didalam tanah. Kehadiran organisme tanah dalam lubang resapan biopori mempercepat proses degradasi sampah organik menjadi pupuk organik (kompos). Kompos merupakan pupuk organik yang 
ramah lingkungan. Untuk mempermudah penggunaannya maka kompos dapat dibentuk menjadi beberapa macam seperti pelet, granul dan sebagainya.

\section{METODE PELAKSANAAN}

Kegiatan program kemitraan masyarakat dilaksanakan di SMAN 4 kabupaten Soppeng, pada bulan Agustus 2018. Khalayak sasaran strategis yaitu warga sekolah terdiri dari kasek, wakasek dan dewan guru yang diharapkan memberikan arahan lebih lanjut ke para siswa-siswi agar peduli lingkungan.

Metode pelaksanaan yang dilakukan pada program kemitraan masyarakat terdiri dari 3 kegiatan yaitu :

A. Pelatihan pembuatan lubang resapan biopori (Santosa et al, 2016)

- Menentukan lingkungan sekolah (halaman)/tanah yang sering digenangi air jika ada hujan.

- Tanah yang akan dibuat lubang resapan disiram air secukupnya kemudian di bor dengan menggunakan bor tanah.

- Lubang resapan dibuat dengan diameter $10 \mathrm{~cm}$ dengan kedalaman $100 \mathrm{~cm}$ (gambar 1).

- Memasukkan pipa paralon kedalam tanah yang sudah di bor

- Permukaan lubang resapan dapat diperhalus dengan memberikan campuran semen

B. Pelatihan pengomposan sampah organik dalam lubang resapan biopori

Adanya kebijakan LISA (LIhat Sampah Ambil) pada sekolah, akan berdampak pada penumpukan sampah organik maka harus segera ada pengelolaan sampah organik untuk mencegah terjadi pembusukan sampah secara alamiah. Sampah organik dimasukkan ke dalam lubang resapan biopori hingga penuh. Sampah menjadi sumber energi bagi organisme tersebut. Sampah yang diuraikan akan menjadi kompos.

\section{Pelatihan pembuatan biogranul kompos}

Kompos yang dihasilkan dari lubang resapan biopori dibentuk menjadi biogranul dengan penambahan limbah air beras untuk menambah kandungan nutrisi. Wulandari (2011), limbah air beras banyak mengandung protein dan vitamin B1.

Sedangkan cara membentuk biogranul kompos sebagai berikut (Isroi, 2010):

- Pengeringan: pengeringan dapat dilakukan dibawah sinar matahari atau menggunakan alat pengering (rotarydryer). Kadar air kompos yang kering $20 \%$, perinsipnya semakin kering semakin bagus.

- Penggilingan dan pengayakan : kompos kering ditumbuk dalam lumpang atau digiling menggunakan mesin. Tingkat kehalusan kompos yang diperlukan minimal 80 mesh. Kompos halus ini kemudian diayak dengan ayakan 80 mesh atau 100 mesh. Sisa bahan yang tidak lolos ayakan ditumbuk kembali sampai halus.

- Penambahan bahan: penambahan bahan untuk meningkatkan kandungan hara kompos dan bahan perekat. Penambahan dapat berupa pupuk an organik. Pada pelatihan ini akan ditambahkan limbah air beras yang kaya protein.

- Granulasi : cara paling sederhana adalah dengan menggunakan nampan biasa. Biasanya ini untuk membuat granul skala kecil atau skala rumah tangga. Bahan yang digunakan sekitar $300 \mathrm{gr}-$ 500 gr. Caranya, bahan dimasukkan ke dalam nampan, ditambahkan limbah air beras 1-5\% dari bahan kompos. Kemudian nampan di goyanggoyang sampai terbentuk granul.

- Pengemasan : setelah granul terbentuk lalu di ayak untuk mendapatkan ukuran granul yang seragam. Ukuran ayakan tergantung pada ukuran granul yang akan di buat. Kemudian baru dapat di kemas.

\section{HASIL PELAKSANAAN}

Pelaksanaan kegiatan program kemitraan masyarakat (PKM) ini dilakukan di SMAN 4 kabupaten Soppeng. Kegiatan dimulai dengan pertemuan awal (audensi) dengan pihak sekolah yang diwakili oleh wakil kepala sekolah yaitu Bapak Drs. Asri. Pertemuan membahas teknis pelaksanaan program pengabdian masyarakat yang akan dilaksanakan oleh tim dosen biologi Fmipa Unhas. Tim pelaksana kegiatan juga melakukan survey 
untuk menentukan lokasi pelatihan pembuatan lubang resapan biopori di sekitar sekolah.

Kegiatan program kemitraan masyarakat dilaksanakan pada hari sabtu , 4 Agustus 2018. Tim pelaksana diterima oleh kepala sekolah di ruang kasek SMAN 4 kabupaten Soppeng (Gambar 1). Pertemuan dengan kepala sekolah membahas tentang PKM Unhas yang dapat mendukung program kementerian lingkungan hidup dan kehutanan yaitu program Adi wiyata . Program Adiwiyata adalah program yang meningkatkan kesadaran warga sekolah untuk peduli lingkungan. Program Adi wiyata ini dilombakan setiap tahun dengan menilai pihak sekolah apa yang diprogramkan untuk menjaga kelestarian lingkungan. Dengan kegiatan PKM ini diharapkan pihak sekolah untuk dapat berpartisipas dan mendorong para warga sekolah untuk ikut program Adi wiyata tersebut.

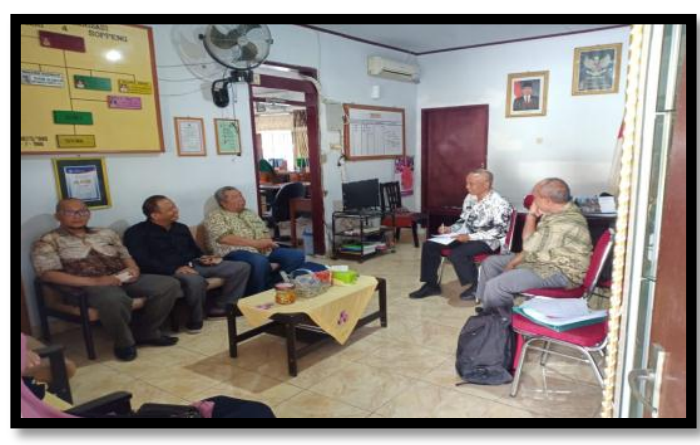

Gambar 1 . Penerimaan Tim PKM oleh Kasek SMAN 4 Kabupaten Soppeng

Adiwiyata merupakan program kementerian lingkungan hidup dan kehutanan yang diadakan setiap tahun untuk mendorong sekolah yang ramah lingkungan. Kegiatan program Adiwiyata adalah mewujudkan kelembagaan sekolah yang peduli dan berbudaya lingkungan bagi sekolah dasar dan menengah di Indonesia. Tujuan program Adiwiyata yaitu menciptakan kondisi yang baik bagi sekolah untuk menjadi tempat pembelajaran \& penyadaran warga sekolah (guru, murid \& pekerja lainnya), sehingga di kemudian hari warga sekolah tersebut dapat turut bertanggung jawab dalam upaya-upaya penyelamatan lingkungan \& pembangunan berkelanjutan. Dengan adanya kegiatan PKM ini diharapkan sekolah SMAN 4 kabupaten Soppeng termotivasi untuk mengikuti program Adi wiyata.

Sosialisasi pembuatan biopori dan biogranul kompos dilaksanakan dihadapan kasek, wakasek, beberapa guru, siswa dan siswi di ruang aula SMAN 4 kabupaten Soppeng. Metode sosialisasi yaitu ceramah dan diskusi. Materi sosialisasi tentang pembuatan biopori dan manfaatnya yang berdampak baik terhadap lingkungan. Pelaksanaan sosialisasi ini menyebabkan peserta mengetahui prosedur pengeboran tanah, penggunaan paralon dan pemanfaatan lubang resapan sebagai tempat pengomposan bahan organik. Tujuan sosialisasi untuk memberikan pengetahui kepada warga sekolah agar mengetahui dan memahami tentang biopori dan biogranul kompos. Sosialisasi ini memberikan efek psikologi bagi warga sekolah sebagai peserta khususnya yaitu percaya diri dan sadar peduli lingkungan (Gambar 2). Pembuatan biopori dan biogranul kompos mudah dan dapat dilakukan oleh warga sekolah.

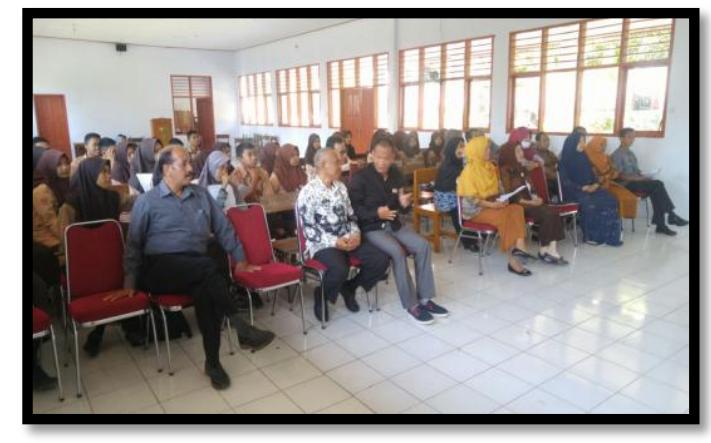

Gambar 2. Sosialisasi pembuatan biopori dan biogranul di SMAN 4 kabupaten Soppeng

Pembuatan biopori dan biopgranul kompos merupakan salah satu kegiatan yang berpengaruh positif terhadap lingkungan. Biopori yang terbentuk dalam jumlah banyak didalam tanah menyebabkan laju resapan air meningkat yang pada akhirnya meningkatkan ketersediaan air dalam tanah. Pemanfaatan sampah organik yaitu seresah daun dan limbah kulit buah yang yang berada di sekolah dapat dikomposkan didalam lubang resapan biopori. Sampah organik tersebut mendorong organisme tanah menuju lubang resapan biopori. Santosa (2018), penggunaan limbah kuliah buah pepaya dan 
mangga yang dimasukkan dalam lubang resapan biopori menyebabkan kehadiran semut, cacing tanah dan serangga tanah lainnya. Organisme tanah tersebut datang ke lubang resapan biopori karena limbah buah tersebut masih mempunyai aroma dan rasa. Sibarani dan Didik (2012), jumlah air yang meresap tergantung dari proses pembentukan biopori pada tiap jenis sampah. Biopori ini terbentuk sebagai hasil dari aktifitas mikroorganisme dalam menguraikan/ mendegradasi sampah. Aktifitas mikroorganisme ini sangat dipengaruhi oleh jumlah makanan yang tersedia (sampah) di dalam lubang biopori. Bila semakin banyak mikroorganisme, maka biopori yang terbentuk juga akan semakin banyak, sehingga jumlah air yang mampu diresapkan pun akan semakin banyak. Sebaliknya jika jumlah biopori dalam tanah yang terbentuk sedikit, maka jumlah air yang dapat diresapkan pun akan semakin kecil.

Hasil pelatihan pembuatan lubang resapan biopori menunjukkan bahwa warga sekolah SMAN 4 kabupaten Soppeng sudah berhasil membuat lubang resapan biopori (Gambar 3). Sekolah mempunyai Lahan /halaman sekolah yang luas dan jika hujan tergenang air. Hilwatullisan (2009), pemanfaatan tanah dan lahan yang tidak sesuai dengan kaidah-kaidah konservasi dan melampaui kemampuan daya dukungnya, akan menyebabkan terjadinya lahan kritis. Disamping itu perilaku masyarakat yang belum mendukung pelestarian tanah dan lingkungan menyebabkan terjadinya bencana alam banjir pada musim penghujan. Untuk menghindari hal tersebut di atas perlu dilakukan suatu upaya pelestarian lahan kritis dan pengembangan fungsi biopori terus ditingkatkan dan disempurnakan. Karuniastutik (2013), biopori pada lahan kritis dimaksudkan untuk memulihkan kesuburan tanah, melindungi tata air dan kelestarian daya dukung lingkungan. Dalam rangka pemanfaatan sumber daya alam baik berupa tanah dan air perlu direncanakan dan dikelola secara tepat melalui suatu sistem pengelolaan Lubang Resapan Biopori. Salah satu upaya pokok dalam pengelolaan LRB adalah berupa pengaturan keseimbangan pada lingkungan yang kurang daerah peresapan. Suwardi
(2016), menjaga ketersediaan air tanah adalah salah satu bagian terpenting didalam kehidupan seharihari. Saat ini sumber air terbesar yang dimanfaatkan oleh manusia berasal dari air tanah. Di daerah perkotaan air tanah sudah berkurang hal ini disebabkan oleh semakin sempitnya lahan terbuka yang berfungsi sebagai peresapan air hujan, banyak lahan produktif beralih fungsi menjadi perumahan dan ruko. Dengan berkurangnya peresapan maka air hujan langsung mengalir kesungai yang selanjutnya menuju ke lautyang semestinya dapat dimanfaatkan sebelumnya.

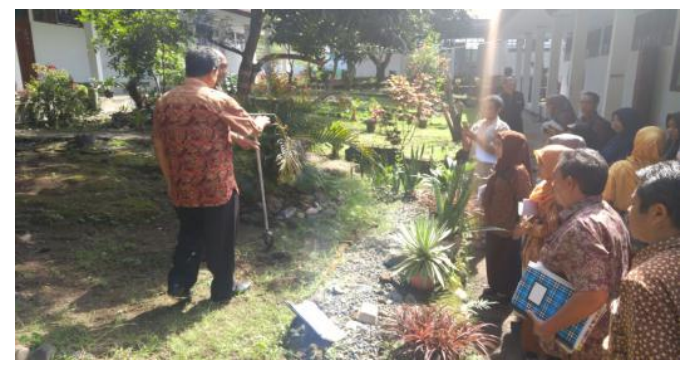

Gambar 3 . Pelatihan pembuatan lubang resapan biopori di Halaman SMAN 4 Soppeng

Pengomposan sampah organik seperti seresah daun dan limbah buah lainnya juga dilakukan warga sekolah di lubang resapan biopori. Hasil pengomposan berupa kompos yang berwarna coklat kehitaman. Kompos tersebut ditumbuk menjadi halus lalu di saring untuk dibentuk menjadi granul. Kompos yang halus dijemur kering sinar matahari. Kompos diperkaya nutrisinya dengan limbah air beras. Wulandari et al., (2011), limbah air beras masih mengadung protein dan hara lainnya yang dapat menjadi pupuk organik. Hasil kegiatan menunjukkan warga sekolah dapat mengetahui cara membuat granul kompos dengan jumlah produksi baru mencapai $1 \mathrm{~kg}$. Kompos bentuk granul bertujuan mempermudah penggunaan bila dijadikan pupuk organik tanaman. Isroi (2010), kompos bentuk pelet dan granul praktis penggunaannya dan tepat sasaran pemanfaatannya. Sayekti (2008), sampah organik dalam lubang resapan biopori akan terdegradasi menjadi produk akhir berupa kompos yang berwarna kecoklatan. 


\section{KESIMPULAN}

Kegiatan ini menyimpulkan bahwa warga sekolah SMAN 4 kabupaten Soppeng sudah mengetahui dan mampu membuat lubang resapan biopori dan biogranul kompos yang diperkaya haranya degan limbah air beras.

\section{REFERENSI}

Arifin S. 2012. Menjaga Kelestarian Lingkungan Dengan Biopori. Prosiding The 4th International Conference on Indonesian Studies. Jakarta.

Brata, K.R. 2009. Lubang Resapan Biopori untuk Mitigasi Banjir, Kekeringan dan Perbaikan. Prosiding Seminar Lubang Biopori (LBR) dapat Mengurangi Bahaya banjir. BPPT. Jakarta.

Hilwatullisan, 2009. Lubang Resapan Biopori (LRB) Pengertian dan Cara Membuatnya. Teknik Kimia Politeknik Negeri Sriwijaya.

Isroi. 2010. Membuat pupuk organik menjadi bentuk granul. https;//isroi.wordpresss.com. Diakses 1 maret 2018.

Karuniastutik, N. 2013. Teknologi biopori untuk mengurangi banjir dan Tumpukan sampah organik. Forum Teknologi, vol.4 (2): 60-68.
Santosa, S. 2018. Effect of Fruits Waste in Biopore Infiltration Hole Toward The Effectiveness of Water Infiltration Rate on Baraya Campus Land of Hasanuddin University. J. Phys.: Conf. Ser. 979012037

Santosa, S., Eddy S., Magdalena L., Dody P dan M. Ruslan Umar. 2016. Pelatihan pembuatan lubang resapan biopori dengan introduksi kokon cacing tanah di Turatea Jeneponto. LPPM Unhas. Makassar

Sayekti, D. 2008. Mengubah sampah organik menjadi kompos dalam lubang resapan biopori UNY. Yogyakarta.

Suwardi. 2016. Pengaruh pemanfaatan biopori sebagai sumber resapan untuk menjaga ke tersedian air tanah di kecamatan Sonrobone, kabupaten Takalar. FST UIN Alauddin. Makassar

Wulandari, C.G.M., S. Muhartini dan S. Trisnowati. 2011. Pengaruh cucian air beras meras dan air beras putih terhadap pertumbuhan dan hasil selada Lactuca sativa L. Faperta UGM, Yogyakarta. 